\title{
Polycyclic Aromatic Hydrocarbons in drinking water of Tehran, Iran
}

\author{
Hamid Karyab", Masud Yunesian ${ }^{1,3^{*}}$, Simin Nasseri ${ }^{1,2}$, Amir Hosein Mahvi ${ }^{1,2}$, Reza Ahmadkhaniha4, \\ Noushin Rastkari ${ }^{3}$ and Ramin Nabizadeh ${ }^{1}$
}

\begin{abstract}
Distribution and seasonal variation of sixteen priority polycyclic aromatic hydrocarbons (PAHs) were investigated in the drinking water of Tehran, the capital of Iran. Detected single and total PAHs concentrations were in the range of 2.01-38.96 and 32.45-733.10 $\mathrm{ng} / \mathrm{L}$, respectively, which were quite high compared to the values recorded in other areas of the world. The average occurrence of PAHs with high molecular weights was $79.55 \%$; for example, chrysene occurred in $60.6 \%$ of the samples, with a maximum concentration of $438.96 \mathrm{ng} / \mathrm{L}$. In addition, mean carcinogen to non-carcinogen PAHs ratio was 63.84. Although the concentration of benzo[a]pyrene, as an indicator of water pollution to PAHs, was lower than the guideline value proposed by World Health Organization (WHO) as well as that of Iranian National Drinking Water Standards for all of the samples, the obtained results indicated that carcinogen PAHs present in the drinking water of Tehran can cause threats to human health.
\end{abstract}

Keywords: Polycyclic aromatic hydrocarbons, Drinking water, Tehran

\section{Introduction}

Drinking water is one of the oldest public health issues and is associated with a multitude of health-related concerns. These concerns are derived into microbial and chemical pollutants, which are comprehensively presented in the international guidelines for drinking water quality [1]. Because of their adverse effects on human and the environment, chemical pollutants, especially xenobiotic compounds, are of foremost importance. The presence of organic pollutants, including endocrine disruptors, organophosphorous pesticides, disinfection by-product precursors, trihalomethanes (THMs), and trichloroethylene (TCE) in water resources have been widely investigated by a large number of studies [2-5]. Polycyclic aromatic hydrocarbons (PAHs) are a group of xenobiotic chemicals which are made up of carbon and hydrogen. They represent a group of contaminants with high melting and boiling points, low vapor pressure, and very low water solubility [6,7]. In the environment, they are mostly derived from anthropogenic activities. However, they can also be

\footnotetext{
* Correspondence: yunesian@tums.ac.ir

${ }^{1}$ Department of Environmental Health Engineering, School of Public Health,

Tehran University of Medical Sciences, Tehran, Iran

${ }^{3}$ Center for Air Pollution Research, Institute for Environmental Research,

Tehran University of Medical Sciences, Tehran, Iran

Full list of author information is available at the end of the article
}

released into the environment through natural incomplete combustion [8]. PAHs are ubiquitous in the environment, which can be frequently found in food [9], air [10], soil [11], and sediments [12]. Additionally, they can be detected in street dust [13], rain water [14], and urban runoffs [15]. PAHs can reach water bodies mainly through dry and wet deposition, road runoff, industrial wastewater, leaching from creosote-impregnated wood, petroleum spills, and fossil fuel combustion [16-19]. They are generally teratogenic, carcinogenic, and mutagenic and may induce lung, bladder, as well as skin cancer. In addition, exposure to high levels of PAHs has been shown to produce immunosuppressive effects and is capable of causing oxidative stress during its metabolism [20-22]. The main objective of the present study was to investigate the distribution and seasonal variation of sixteen PAHs, as priority pollutants recognized by U.S. Environmental Protection Agency (EPA), in the drinking water of Tehran, the capital of Iran.

\section{Materials and methods}

Based on drinking water supply, Tehran was divided into six districts. Four water samples were collected from each district in each season over the period from July 2011 to May 2012 (i.e. a total of 99 samples). In order to prevent 
unwanted reactions, samples were collected in $1000 \mathrm{~mL}$ amber glass bottles with Teflon lined tops. Each sample was stored in a cooler at $4^{\circ} \mathrm{C}$ while being transported to the laboratory. Standard solutions of sixteen PAHs $(10 \mathrm{mg} / \mathrm{L}$ in acetonitrile), including naphthalene (Nap), acenaphthylene (Acy), acenaphthene (Ace), fluorene (Fl), phenanthrene (Phe), anthracene (Ant), fluoranthene (Flu), pyrene (Pyr), benzo[a]anthracene (BaA), chrysene (Chy), benzo[a]pyrene $(\mathrm{BaP})$, benzo[b]fluoranthene $(\mathrm{BbF})$, benzo [k]fluoranthene $(\mathrm{BkF})$, dibenzo[a,h]anthracene (DahA), indeno[1,2,3-cd]pyrene (IcdP), and benzo[g,h,i]perylene (BghiP) were purchased from Supelco Company, USA. C18 extraction cartridge was purchased from Chromaband (Manchery-Nagel, Germany). A solid-phase extraction (SPE) vacuum manifold was used for concentration and purification of solvent extracts. In addition, cyclohexane, acetone, biphenyl, and methanol were of analytical-reagent grade (Merck, Germany).

Water samples were extracted using a solid phase extraction (SPE) system according to the established procedures [23]. The applied extraction method was suitable for the extraction of a wide range of analytes, as elaborated in the EPA methods 3535A [24]. To avoid adsorption of PAHs upon glassware, $5 \mathrm{ml}$ of methanol was added to the samples. The solution was mixed after adding $1 \mu \mathrm{L}$ biphenyl to methanol $(1 \mu \mathrm{g} / \mathrm{L}$, as internal standard). Prior to extraction, the SPE cartridge was conditioned with $5 \mathrm{ml}$ of methanol under vacuum conditions, followed by $5 \mathrm{ml}$ of ultra pure water. $1000 \mathrm{ml}$ of

Table 1 Method parameters and analytical results for PAHs components

\begin{tabular}{lccccc}
\hline $\begin{array}{l}\text { Compounds } \\
\text { PAHs }\end{array}$ & $\begin{array}{c}\mathbf{t}_{\mathbf{R}} \\
(\mathbf{m i n})\end{array}$ & $\begin{array}{c}\text { Selected ions for } \\
\text { mass spectrometry } \\
\text { quantification }\end{array}$ & $\begin{array}{c}\mathbf{R}^{\mathbf{2}} \text { in } \\
\text { calibration }\end{array}$ & $\begin{array}{c}\text { Mean } \\
\text { recovery } \\
\mathbf{( \% )}\end{array}$ \\
\cline { 2 - 5 } Nap & 7.99 & $127-129$ & 128 & 0.99 & 36.28 \\
\hline Acy & 11.66 & $151-153$ & 152 & 0.99 & 68.14 \\
\hline Ace & 12.08 & $152-154$ & 153 & 0.99 & 82.94 \\
\hline Fl & 13.30 & $165-167$ & 166 & 0.99 & 59.10 \\
\hline Phe & 15.60 & $177-179$ & 178 & 0.98 & 112.24 \\
\hline Ant & 17.76 & $177-179$ & 178 & 0.98 & 97.03 \\
\hline Flu & 18.60 & $201-203$ & 202 & 0.99 & 74.50 \\
\hline Pyr & 19.06 & $201-203$ & 202 & 0.99 & 82.00 \\
\hline BaA & 21.94 & $227-229$ & 228 & 0.97 & 79.74 \\
\hline Chy & 22.03 & $227-229$ & 228 & 0.96 & 64.54 \\
\hline BbF & 24.63 & $251-253$ & 252 & 0.96 & 108.14 \\
\hline BkF & 24.50 & $251-253$ & 252 & 0.98 & 117.82 \\
\hline BaP & 24.80 & $251-253$ & 252 & 0.98 & 69.70 \\
\hline IcdP & 28.70 & $275-277$ & 276 & 0.98 & 80.23 \\
\hline DahA & 28.80 & $275-277$ & 276 & 0.98 & 132.57 \\
\hline BghiP & 29.76 & $277-279$ & 278 & 0.98 & 47.83 \\
\hline & & & & & \\
\hline
\end{tabular}

the water sample was passed through the cartridge at a flow rate of $20 \mathrm{ml} / \mathrm{min}$. After percolating all samples through the cartridge and drying the wall of the separating funnel, the cartridge was centrifuged at $2500 \mathrm{rpm}$ for $10 \mathrm{~min}$ to remove the residential water. Then, the cartridge was dried with an air stream for $10 \mathrm{~min}$, which was followed by adding $200 \mathrm{ml}$ of acetone to vapor residual water. The elution was performed with $5 \mathrm{ml}$ cyclohexane. The extract was dried under a gentle stream of nitrogen at $40^{\circ} \mathrm{C}$. The extract was raised into the micro vial (100 micro liters) and preserved in the refrigerator until being injected into the GC/MS instrument. The PAHs extracts were analyzed by using a 3800 Varian gas chromatography coupled to a Varian Saturn 2200 mass spectrometer, equipped with a $30 \mathrm{~m} \times 0.25 \mathrm{~mm}$ i.d. WCOT CP-Sil 8 CB column. The GC/MS operated under the following conditions: the initial column temperature was $70^{\circ} \mathrm{C}$. After an initial holding time of $1 \mathrm{~min}$, the temperature was programmed to rise to $300^{\circ} \mathrm{C}$ at a rate of $10^{\circ} \mathrm{C} / \mathrm{min}$ for $30 \mathrm{~min}$. The injector and detector temperatures were $250^{\circ} \mathrm{C}$ and $300^{\circ} \mathrm{C}$, respectively. Helium was used as the carrier gas at a flow rate of $2 \mathrm{ml} / \mathrm{min}$. Method was according to the established procedure by Li et al. (2001) and the EPA method 8270D

Table 2 Annually means concentrations of sixteen PAHs in distribution system ( $\mathrm{ng} / \mathrm{L}$ )

\begin{tabular}{|c|c|c|c|c|}
\hline $\begin{array}{l}\text { Compounds } \\
\text { PAHs }\end{array}$ & $\begin{array}{c}\text { Occurrence } \\
\text { single PAHs } \\
\text { (\%) }\end{array}$ & $\begin{array}{l}\text { Occurrence in } \\
\text { total detected } \\
\text { PAHs }(n, \%)\end{array}$ & $\begin{array}{l}\text { Range } \\
\text { (ng/L) }\end{array}$ & $\begin{array}{l}\text { Mean } \\
\text { (ng/L) }\end{array}$ \\
\hline Nap & 46.50 & 46(19.1) & ND-63.1 & 4.6 \\
\hline Acy & 5.05 & $5(2.1)$ & ND-3.04 & - \\
\hline Ace & 2.02 & $2(0.8)$ & ND-2.33 & - \\
\hline$\overline{\mathrm{FI}}$ & $\mathrm{ND}^{3}$ & ND & - & - \\
\hline Phe & 2.02 & $2(0.8)$ & ND-3.43 & - \\
\hline Ant & ND & ND & - & - \\
\hline Flu & ND & ND & - & - \\
\hline Pyr & ND & ND & - & - \\
\hline $\mathrm{BaA}$ & 21.20 & $21(8.7)$ & ND-34.05 & 2.29 \\
\hline Chy & 60.60 & $60(25)$ & ND-438.96 & 27.35 \\
\hline $\mathrm{BbF}$ & 18.18 & $18(7.5)$ & ND-24.39 & 2.15 \\
\hline $\mathrm{BkF}$ & 21.20 & $21(8.7)$ & ND-203.75 & 11.21 \\
\hline $\mathrm{BaP}$ & 11.10 & $11(4.6)$ & ND-10.77 & 1.33 \\
\hline $\mathrm{IcdP}$ & 23.20 & $23(9.5)$ & ND-277.51 & 19.70 \\
\hline DahA & 31.30 & $31(12.9)$ & ND-114.61 & 6.09 \\
\hline BghiP & 28.90 & $28(11.6)$ & ND-67.74 & 3.24 \\
\hline Total PAHs & - & & $32.45-733.10$ & 85.07 \\
\hline Concentrations as BaP ${ }^{1}$ & - & & $3.14-219.59$ & 35.60 \\
\hline$\overline{\Sigma \text { Carcinogen } \mathrm{PAHs}^{2}}$ & - & & $6.00-575.00$ & 38.62 \\
\hline
\end{tabular}


$[23,24]$. PAHs concentrations were identified based on their retention times and confirmed by comparing their mass spectra with the reference library. Calibration curves were plotted at seven concentration levels from 2 to $2000 \mathrm{ng} / \mathrm{L}$ with standard solutions containing all studied PAHs. Detection limit (DL) for individual PAHs, with a signal to noise ratio of 3 , ranged from 0.8 to $2 \mathrm{ng} / \mathrm{L}$. Concentrations that were below the DLs were assigned as not determined; in such cases, half of the $\mathrm{DL}$ value for that substance was considered for the calculations.

\section{Results and discussions}

The mean recovery rate for single PAHs ranged from 36.28 to $132.57 \%$ of applied concentration. The lowest recovery rates belonged to Nap (36.28\%) and BghiP (47.83\%), while the highest recovery rates belonged to DahA (132.57\%) and BkF (117.82\%) (Table 1). The concentrations of single PAHs in the distribution system ranged from not-detectable to $438.96 \mathrm{ng} / \mathrm{L}$. As shown in Table 2, the concentration was higher than that found in Jiangsu province, China, [25], which was in the range of 0.1-10.2 ng/L. Except for Fl, Ant, Flu and Phy, all PAHs were detected in the water samples during the study period. The maximum single PAH concentrations (ng/L) were assigned to Chy (438.96), IcdP (277.51), BkF (203.75), DahA (114.61), BghiP (67.74), and Nap (63.10). Total occurrences of single PAHs were 269 times, which $79.55 \%$ was assigned to highmolecular-weight (HMW) PAHs. Chy occurred most frequently, i.e. in $60.6 \%$ of the samples, followed by Nap (46.5\%) and DahA (31.3\%). Results were not in agreement with those reported by Kabzinski et al. (2002), who found that the main components of PAHs mixture in the drinking water were Nap, Acy, Fl, and Ant [26].

A broad range of the total PAHs concentrations, i.e. from 32.45 to $733.10 \mathrm{ng} / \mathrm{L}$, was observed in different sampling points. The mean total PAHs concentration (85.07 ng/L) was comparable with that found in Helsinki, i.e. $150.3 \mathrm{ng} / \mathrm{L}$, and Horsholm, i.e. $106.5 \mathrm{ng} / \mathrm{L}$ [27]. However, it was lower than the concentrations detected in Kaoshing, i.e. $1452.9 \mathrm{ng} / \mathrm{L}$ [28], and Meet Faris, i.e. $1127 \mathrm{ng} / \mathrm{L}$ [29]. Badawy and Emababy evaluated PAHs distribution in the drinking water of four

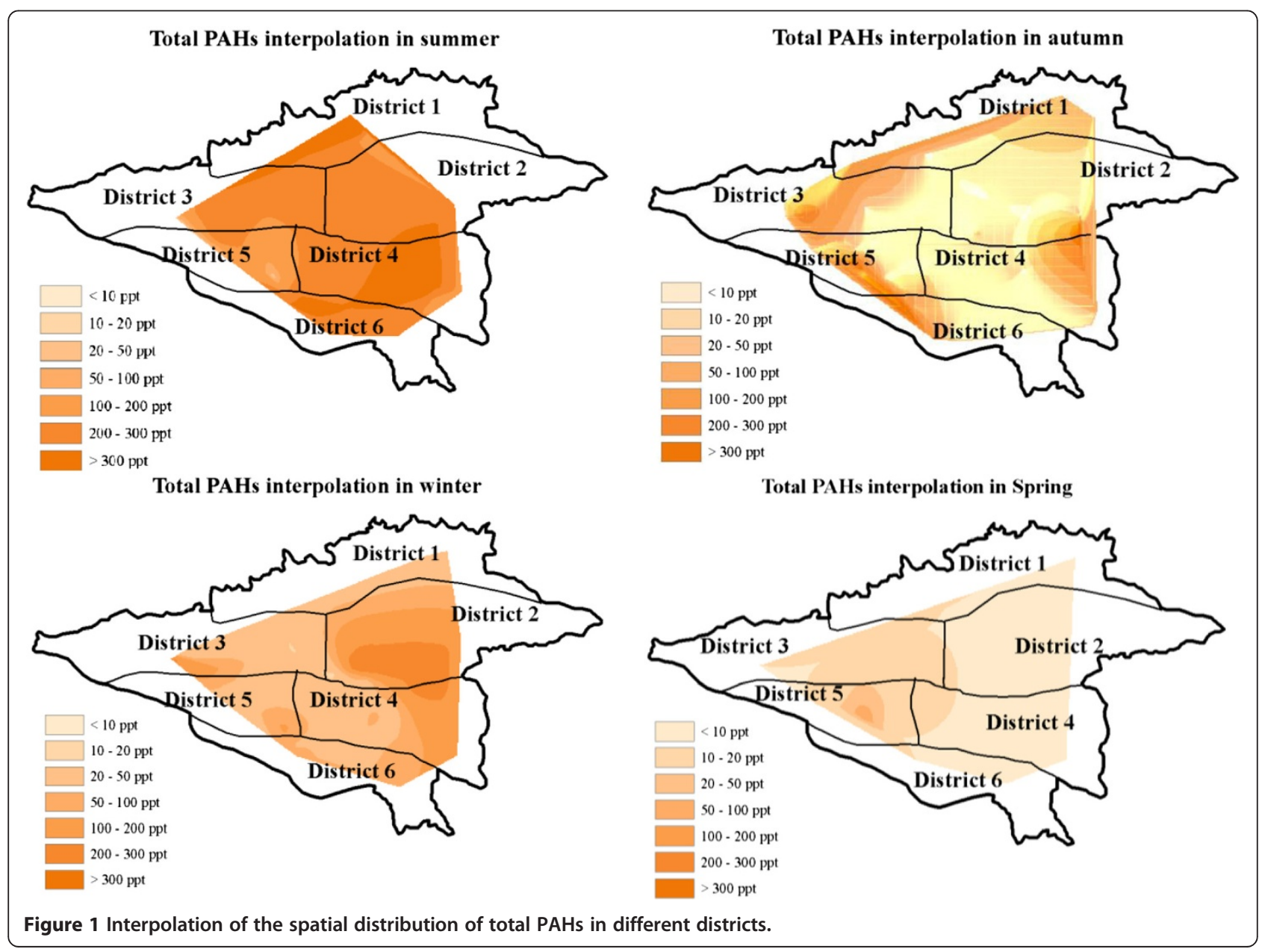




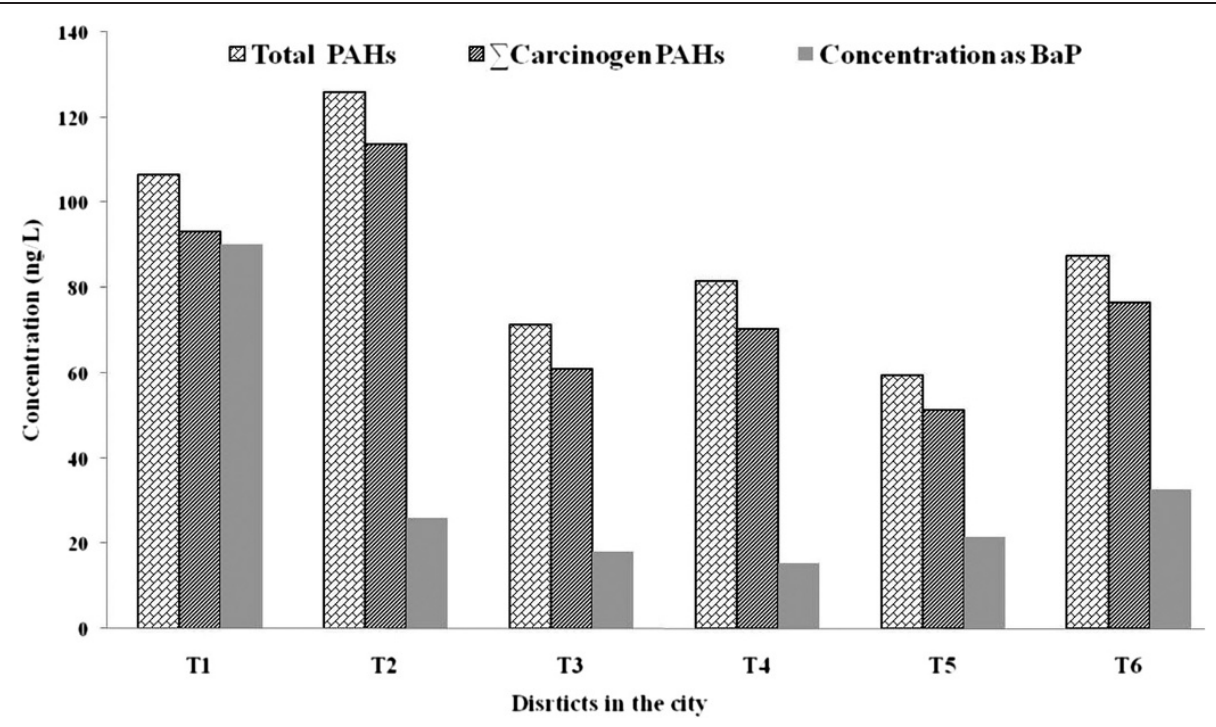

Figure 2 PAHs components concentration in different districts in tap water (ng/L).

cities in Egypt and found that total PAHs fluctuated in the range of $703-1238 \mathrm{ng} / \mathrm{L}$, which $80 \%$ belonged to 4-, 5-, and 6-ring PAHs. Their latest results were consistent with those observed in the present study, which demonstrated that the contribution of HMW PAHs was $79.55 \%$.

Toxic equivalency factor (TEF) was used to evaluate single PAHs concentrations as BaP equivalent. TEF is an estimate of the relative toxicity of a $\mathrm{PAH}$ compared to that of Bap [7]. Results demonstrated that the mean PAHs concentration as $\mathrm{BaP}$ equivalent was in the range of 3.14-219.59 $\mathrm{ng} / \mathrm{L}$ in the water samples. The carcinogenic PAHs concentration, including $\mathrm{BaA}, \mathrm{BbF}, \mathrm{BkF}$, Chy, BaP, DBahA, and IcdP, which are probable human carcinogens according to the U.S. EPA (2002), were identified in the drinking water samples [30]. Sum of carcinogen PAHs ranged from 6.00 to $575.00 \mathrm{ng} / \mathrm{L}$ in various seasons. The maximum concentration of carcinogen PAHs was observed in summer, which was similar to the results from the study of Kabzinski et al. (2002). Carcinogen to non-carcinogen PAHs ratios varied from 8.12 to $98.48 \%$, with an average of $63.84 \%$.
Detected concentrations of BaP, a carcinogen PAHs, ranged between 4.28 to $10.77 \mathrm{ng} / \mathrm{L}$ in summer and autumn, which is lower than the guideline values proposed by WHO [31] as well as that of Iranian National Drinking Water Standards [32]. However, in one sample, $\mathrm{BaP}$ concentration was recorded to be higher than the recommended value of European Union. The allowable level of PAHs in European Union's drinking water standard is $10 \mathrm{ng} / \mathrm{L}$ for $\mathrm{BaP}$ and $100 \mathrm{ng} / \mathrm{L}$ for carcinogen PAHs [33]. In addition, the concentrations of carcinogen PAHs in 12 samples were higher than European Union's drinking water standards.

The concentration of the single PAHs and total PAHs in the drinking water shows important variations depending on the seasonal variations. The highest concentrations of total PAHs were detected in summer, which ranged between 22.31 to $733.10 \mathrm{ng} / \mathrm{L}$, with an average of $277.35 \mathrm{ng} / \mathrm{L}$. Our results were lower than those detected by Kabzinski et al. (2002). They found that total PAHs concentration ranged from 38 to $4953 \mathrm{ng} / \mathrm{L}$. In addition, they demonstrated that the highest PAHs contents took place in July-September, which was in agreement with

Table 3 Comparing the results and PAHs standards in drinking water (ng/L)

\begin{tabular}{|c|c|c|c|c|c|}
\hline Components & USEPA [20] & WHO [31] & ISIRI [32] & EU [33] & Results \\
\hline $\mathrm{BaP}$ & 200 & 700 & 700 & 10 & $\begin{array}{l}\mathrm{ND}-10.77 \\
\text { (mean: } 1.33 \text { ) }\end{array}$ \\
\hline Sum of BaP, BbF, BkF, Chy and DBahA & 200 & - & - & - & $\begin{array}{l}5.21-472.47 \\
\text { (mean: } 48.12 \text { ) }\end{array}$ \\
\hline Sum of BbF, BkF, BghiP and IcdP & - & - & - & 100 & $\begin{array}{l}4.06-569.72 \\
\text { (mean: } 36.30)\end{array}$ \\
\hline
\end{tabular}


our results. To present seasonal variation of total PAHs concentration, interpolation of pollutants in the distribution system was achieved with the natural neighbor method, the commonly used interpolation method in ARC GIS 9.2 (Figure 1). In this method, weights are computed based on the areas rather than distances from the surrounding points [34].

Result indicated that the concentration of total PAHs in the drinking water of Tehran varies according to the geographical location. The maximum PAHs concentration was observed in district T2 (Figure 2). The main reason for PAHs presence in the distribution system can be the pollution of water sources as well as leaching from pipelines [7]. Trend of PAHs variations in the distribution system, except for winter, was comparable with PAHs concentrations in water resources. It was suggested that the highest PAHs concentration in Karaj River, the main source of drinking water for Tehran, was in summer (an unpublished observation). Comparison of PAHs concentrations in water sources and those present in the distribution system suggested that there existed significant similarity between them. In Tehran Water Treatment Plant, drinking water passes through conventional treatment operations, including coagulation, flocculation, sedimentation, sand filtration, and disinfections. Removal efficiencies of PAHs by conventional treatment processes are reported to be in the range of $20-100 \%$ $[29,35]$. Therefore, the conventional water treatment processes are not efficient for the removal of PAHs from drinking water supplies, and water sources can be an important route for drinking water pollution to PAHs. The main sources of PAH contamination in drinking water are rarely the raw water source; rather, the coating of the drinking water distribution pipes with coal tar is mainly responsible [7]. Coal tar is used to give effective protection against corrosion. Water disinfection by chlorine and anaerobic condition remobilized PAHs from the coal tar lining [36,37].

\section{Conclusion}

- The first integrated investigation of PAHs in the drinking water of Tehran revealed that some individual HMW PAHs, such as Chy, BkF, and IcdP, are present in levels higher than that of European Union's drinking water standard, whereas, the permissible level for PAHs in drinking water by WHO and Iranian National Drinking Water Standards is only set for BaP.

- In the previous studies, several organic pollutants, including THMs and halo acetic acids, were identified in Tehran water sources [38-40]. Detection of PAHs in the present study shows that there are serious pollutants in water sources; it also indicates the inefficiency of water resources management in Tehran.

- The PAH profiles in the distribution system were similar to those of surface water observed in Karaj river, which is the important source of drinking water for Tehran. The high PAHs concentrations in the summer may be the result of a high concentration of PAHs in water sources, which was observed in another part of this study (unpublished observations).

- In all sampling points, the concentration of $\mathrm{BaP}$ in the drinking water was lower than $700 \mathrm{ng} / \mathrm{L}$, as recommended by WHO [31] and Iranian National Drinking Water Standards [32]. However, the concentrations of carcinogen PAHs in 12\% of samples were higher than European Union's drinking water standard, which forces that the total concentration of PAHs should not exceed $100 \mathrm{ng} / \mathrm{L}$. In Table 3 results of detected PAHs is compared with national and international standards.

- To protect drinking water sources as well as to prevent adverse effects on humans and biota, authors' recommendations are as below:

1. Full protection of water sources, including suppression of commercial, residential, and recreational activities in the vicinity of rivers and dams;

2. To establish national as well as international standards for permissible levels of individual polycyclic aromatic hydrocarbons, especially carcinogen PAHs;

3. To remove PAHs from water sources by advanced water treatment technologies; also, to prevent chlorinated-PAHs formation in the drinking water during chlorination $[41,42]$.

\section{Competing interests}

The authors declare that they have no competing interests.

\section{Authors' contributions}

Authors contributed to the article as follows: MY supervised the study. He was involved in study design and interpretation of results. HK was responsible for sample collection, data analysis, summarization of results and manuscript preparation. RA was responsible for analysis of PAHs in water samples collected in this study. SN, AHM and RN were participated in designing the field studies, data processing and analysis. They gave general support in interpretation of results and manuscript preparation. All authors read and approved the final manuscript.

\section{Acknowledgements}

This study was part of a PhD dissertation supported by Tehran University of Medical Sciences (grant No: 90-02-27-14151).

\section{Author details}

${ }^{1}$ Department of Environmental Health Engineering, School of Public Health, Tehran University of Medical Sciences, Tehran, Iran. ${ }^{2}$ Center for Water Quality Research, Institute for Environmental Research, Tehran University of Medical Sciences, Tehran, Iran. ${ }^{3}$ Center for Air Pollution Research, Institute for Environmental Research, Tehran University of Medical Sciences, Tehran, Iran. 
${ }^{4}$ Department of Human Ecology, School of Public Health, Tehran University of Medical Sciences, Tehran, Iran.

Received: 25 August 2012 Accepted: 10 July 2013

Published: 5 August 2013

\section{References}

1. Fehr R, Mekel O, Lacombe M, Wolf U: Towards health impact assessment of drinking-water privatization-the example of waterborne carcinogens in North Rhine-Westphalia Germany). B World Health Organ 2003, 81(6):408-414

2. Berryman D, Houde F, DeBlois C, O'Shea M: Nonylphenolic compounds in drinking and surface waters downstream of treated textile and pulp and paper effluents: a survey and preliminary assessment of their potential effects on public health and aquatic life. Chemosphere 2004, 56(3):247-255.

3. Dobaradaran S, Mahvi AH, Nabizadeh R, Mesdaghinia A, Naddafi K, Yunesian M, Rastkari N, Nazmara S: Hazardous organic compounds in groundwater near Tehran automobile industry. Bull Environ Contam Toxicol 2010, 85(5):530-533.

4. Karyab H, Mahvi AH, Nazmara S, Bahojb A: Determination of water sources contamination to diazinon and malathion and spatial pollution patterns in Qazvin, Iran. Bull Environ Contam Toxicol 2012, 90(1):126-131.

5. Jafari AJ, Abasabad RP, Salehzadeh A: Endocrine disrupting contaminants in water resources and sewage in HAMADAN City of IRAN. Iran J Environ Health Sci Eng 2009, 6(2):89-96.

6. Mackay D, Shiu WY, Ma KC, Lee SC: Handbook of Environmental Physical-Chemical Properties and Environmental Fate for Organic Chemicals. 2nd edition: CRC press, Taylor and Francis group, Boca Raton, Florida; 2006

7. WHO: Polynuclear aromatic hydrocarbons in Drinking-water, Background document for development of WHO Guidelines for Drinking-water Quality. Geneva: World Health Organization. http://www.who.int/water_sanitation_ health/dwq/chemicals/polyaromahydrocarbons.pdf

8. Olivella MA, Ribalta TG, de Febrer AR, Mollet JM, de Las Heras FX: Distribution of polycyclic aromatic hydrocarbons in riverine waters after Mediterranean forest fires. Sci Total Environ 2006, 355(1-3):156-166.

9. Martorell I, Perelló G, Martí-Cid R, Castell V, Llobet JM, Domingo JL: Polycyclic aromatic hydrocarbons (PAH) in foods and estimated PAH intake by the population of Catalonia, Spain: temporal trend. Environ Int 2010, 36(5):424-432

10. Halek F, Nabi GH, Ganjidoust H, Keyanpour M, Mirmohammadi M: Particulate polycyclic aromatic hydrocarbons in urban air of Tehran. Iran J Environ Health Sci Eng 2006, 3(3):247-254.

11. Maliszewska-Kordybach B, Smreczak B, Klimkowicz-Pawlas A Concentrations, sources, and spatial distribution of individual polycyclic aromatic hydrocarbons (PAHs) in agricultural soils in the Eastern part of the EU: Poland as a case study. Sci Total Environ 2009, 407(12):3746-3753.

12. Perra G, Pozo K, Guerranti C, Lazzeri D, Volpi V, Corsolini S, Focardi S: Levels and spatial distribution of polycyclic aromatic hydrocarbons (PAHs) in superficial sediment from 15 Italian marine protected areas (MPA). Mar Pollut Bull 2011, 62(4):874-877.

13. Lorenzi D, Entwistle JA, Cave M, Dean JR: Determination of polycyclic aromatic hydrocarbons in urban street dust: implications for human health. Chemosphere 2011, 83(7):970-977.

14. Olivella MÀ: Polycyclic aromatic hydrocarbons in rainwater and surface waters of Lake Maggiore, a subalpine lake in Northern Italy. Chemosphere 2006, 63(1):116-131.

15. Mahvi A, Mardani G: Determination of Phenanthrene in Urban Runoff of Tehran, Capital of Iran. Iran J Environ Health Sci Eng 2005, 2:5-11.

16. Ngabe B, Bidleman TF, Scott Gl: Polycyclic aromatic hydrocarbons in storm runoff from urban and coastal South Carolina. Sci Total Environ 2000, 255(1-3):1-9.

17. Park JS, Wade TL, Sweet ST: Atmospheric deposition of PAHs, PCBs, and organochlorine pesticides to Corpus Christi Bay, Texas. Atmos Environ 2002, 36(10):1707-1720.

18. Vogelsang C, Grung M, Jantsch TG, Tollefsen KE, Liltved H: Occurrence and removal of selected organic micropollutants at mechanical, chemical and advanced wastewater treatment plants in Norway. Water Res 2006, 40(19):3559-3570.
19. Vidal M, Domínguez J, Luís A: Spatial and temporal patterns of polycyclic aromatic hydrocarbons (PAHs) in eggs of a coastal bird from northwestern Iberia after a major oil spill. Sci Total Environ 2011, 409(13):2668-2673.

20. ATSDR: Toxicological Profile for Polycyclic Aromatic Hydrocarbons (PAHS), Public Health Service, U.S. Department of Health and Human Services. Altanta, GA: Agency for Toxic Substances Disease Registry. www.atsdr. cdc.gov/toxprofiles/tp.asp?id=122\&tid $=25$

21. Binková B, Šrám RJ: The genotoxic effect of carcinogenic PAHs, their artificial and environmental mixtures (EOM) on human diploid lung fibroblasts. Mutat Res-Fund Mol M 2004, 547(1-2):109-121.

22. Singh VK, Patel DK, Jyoti, Ram S, Mathur N, Siddiqui MK: Blood levels of polycyclic aromatic hydrocarbons in children and their association with oxidative stress indices: an Indian perspective. Clin Biochem 2008, 41(3):152-161

23. Li N, Lee HK: Solid-phase extraction of polycyclic aromatic hydrocarbons in surface water: negative effect of humic acid. J Chromatogr A 2001, 921(2):255-263.

24. US.EPA: Drinking Water Analytical Methods, Analytical Methods Approved for Drinking Water Compliance Monitoring. www.epa.gov/ogwdw/methods/ analyticalmethods_ogwdw.htm

25. Li B, Qu C, Bi J: Identification of trace organic pollutants in drinking water and the associated human health risks in Jiangsu Province, China. Bull Environ Contam Toxicol 2012, 88(6):880-884.

26. Kabzinski AKM, Cyran J, Juszczak R: Determination of polycyclic aromatic hydrocarbons in water (including drinking water) of Lodz. Pol J Environ Stud 2002, 11(6):695-706.

27. Manoli E, Samara C, Konstantinou I, Albanis T: Polycyclic aromatic hydrocarbons in the bulk precipitation and surface waters of Northern Greece. Chemosphere 2000, 41(12):1845-1855.

28. Chen HW: Distribution and risk assessment of polycyclic aromatic hydrocarbons in household drinking water. Bull Environ Contam Toxicol 2007, 78(3-4):201-205.

29. Badawy MI, Emababy MA: Distribution of polycyclic aromatic hydrocarbons in drinking water in Egypt. Desalination 2010, 251(1-3):34-40.

30. USEPA: Polycyclic Organic Matter. Washington, DC: Environmental Protection Agency; 2002. http://www.epa.gov/ttn/atw/hlthef/polycycl.html

31. WHO: Guidelines for Drinking-water Quality. 4th edition. World Health Organization; 2011. whalibdoc.who.int/publications/2011/9789241548151_ eng.pdf

32. ISIRI: Drinking water-Physical and chemical specifications, 1053, 5th. revision, Institute of Standards and Industrial Research of Iran; 2010. http://www.isiri.org/Portal/File/ShowFile.aspx?ID=1af17a3d-649c-4eada8d3-7ffb480bfa41

33. European Communities: The quality of water intended for human consumption. Official Journal of the European Communities 1998. Counci Directive 98/83/EC. http://www.fsai.ie/uploadedFiles/Legislation/ Food_Legisation_Links/Water/EU_Directive_98_83_EC.pdf

34. Merwade VM, Maidment DR, Goff JA: Anisotropic considerations while interpolating river channel bathymetry. J Hydrol 2006, 331(3-4):731-741.

35. Stackelberg PE, Gibs J, Furlong ET, Meyer MT, Zaugg SD, Lippincott RL: Efficiency of conventional drinking-water-treatment processes in removal of pharmaceuticals and other organic compounds. Sci Total Environ 2007, 377(2-3):255-272.

36. Deborde $M$, von Gunten U: Reactions of chlorine with inorganic and organic compounds during water treatment-Kinetics and mechanisms: a critical review. Water Res 2008, 42(1-2):13-51.

37. Maier M, Maier D, Lloyd BJ: Factors influencing the mobilisation of polycyclic aromatic hydrocarbons (PAHs) from the coal-tar lining of water mains. Water Res 2000, 34(3):773-786.

38. Zazouli MA, Nasseri S, Hazratilivari M: Chemical fractions of natural organic matter in two water treatment plants of Tehran and DBPS formation potential. Toxicol Lett 2009, 189:S136. Supplement.

39. Pardakhti AR, Bidhendi GR, Torabian A, Karbassi A, Yunesian M: Comparative cancer risk assessment of THMs in drinking water from well water sources and surface water sources. Environ Monit Assess 2011, 179(1-4):499-507.

40. Ghoochani M, Rastkari N, Nazmara S, Mahvi AH, Nabizadeh R: Survey of the Concentration of Halo Acetic Acids in Tehran Drinking Water: September 2011; 
12th International conference on environmental science and technology.

Rhodes, Greece; 2011. www.srcosmos.gr/srcosmos/showpub.aspx?aa=15045

41. Vilhunen $S$, Vilve $M$, Vepsäläinen $M$, Sillanpää M: Removal of organic matter from a variety of water matrices by UV photolysis and UV/H2O2 method. J Hazard Mater 2010, 179(1-3):776-782.

42. Sankoda K, Nomiyama K, Yonehara T, Kuribayashi T, Shinohara R: Evidence for in situ production of chlorinated polycyclic aromatic hydrocarbons on tidal flats: environmental monitoring and laboratory scale experiment. Chemosphere 2012, 88(5):542-547.

doi:10.1186/2052-336X-11-25

Cite this article as: Karyab et al:: Polycyclic Aromatic Hydrocarbons in drinking water of Tehran, Iran. Journal of Environmental Health Sciences \& Engineering 2013 11:25.

\section{Submit your next manuscript to BioMed Central and take full advantage of:}

- Convenient online submission

- Thorough peer review

- No space constraints or color figure charges

- Immediate publication on acceptance

- Inclusion in PubMed, CAS, Scopus and Google Scholar

- Research which is freely available for redistribution 